\title{
A note on the geometry of three circles
}

\section{R. Pacheco, F. Pinheiro and R. Portugal}

\section{ABSTRACT.}

In the present note, we deduce some nice results concerning the geometry of three-circles from an easy incidence lemma in plane projective geometry. By particularizing to the case of the three excircles of a triangle, this lemma provides a unified geometric characterization of many interesting Kimberling centers.

DePARTAMENTO DE MATEMÁtica

UNIVERSIDADE DA BEIRA INTERIOR

RUA MARQUÊS D'ÁVILA E BOLAMA, 6201-001, COVILHÃ - PORTUGAL

E-mail address: rpacheco@ubi.pt; a20226@ubi.pt; portugal.ptesapo.pt 